\title{
O PRINCÍPIO DA SEGURANÇA JURÍDICA E A RELAÇÃO FISCO-CONTRIBUINTE
}

\author{
The principle of legal certainty and the tax-payer relation
}

\section{Alexandre Prevedello}

Mestre em Direito pela Fundação Escola Superior do Ministério Público do Rio Grande do Sul (2018). Especialista em Direito Constitucional pela Universidade do Sul de Santa Catarina (2009). Especialista em Processo Civil pela Universidade Federal do Rio Grande do Sul (2008). Graduado em Direito pela Pontifícia Universidade Católica do Rio Grande do Sul (2004). Assessor de Desembargador no Tribunal de Justiça do Estado do Rio Grande do Sul.

\section{Lucca Silveira Finocchiaro}

Graduado em Direito pelo Fundação Escola Superior do Ministério Público - RS (2012). Especialista em Pós-Graduação em Direito Público pela Pontifícia Universidade Católica do Rio Grande do Sul (2015). Mestre em Mestrado em Direito pelo Fundação Escola Superior do Ministério Público (RS) (2018). Juiz Leigo do Foro Regional do Partenon da Tribunal de Justiça do Estado do Rio Grande do Sul. Advogado da Amir Sarti Advogados Associados.

\section{Resumo}

Este ensaio investiga, mediante uma abordagem dedutiva, o princípio da segurança jurídica, que é inseparável dos ideais do Estado Democrático de Direito e se consubstancia em um dos fundamentos da República Federativa do Brasil. Examina-se a evolução e o atual conteúdo da segurança jurídica no âmbito da relação jurídico-tributário, especialmente sob a dimensão da proteção da legítima confiança, apresentando-se, ainda, seus principais aspectos relacionados à atuação dos poderes Legislativo, Executivo e Judiciário.

Palavras-chave: Segurança jurídica. Proteção à confiança. Fisco. Contribuinte. Poderes constituídos.

\section{Abstract}

This essay investigates, through a deductive approach, the Principle of Legal Certainty, which is inseparable of the Democratic State Principles and it consubstantiates in one of the principles of the Federative Republic of Brazil. It investigates the evolution and the current content of legal certainty in the legal-tax relation, especially under the dimension of legitimate expectations. The essay also presents the main aspects of the Principle of Legal Certainty related to the performance of the Legislative, Executive and Judiciary powers.

Keywords: Legal Certainty. Protection of expectation. Treasure. Taxpayer. Constituted powers.

\section{Sumário}

1. Introdução; 2. Segurança jurídica como elemento indissociável dos sistemas jurídicos (civil e common law) e do estado democrático brasileiro; $2.1 \mathrm{~A}$ evolução do princípio da segurança jurídica como proteção à confiança; $2.2 \mathrm{O}$ conteúdo da "proteção da legítima confiança" na relação fisco-contribuinte; 3. Proteção da legítima confiança, os poderes constituídos e a relação fisco-contribuinte; 3.1 Principais aspectos da segurança jurídica relacionados à atuação do legislativo (parlamento); 3.2 Principais aspectos da segurança jurídica relacionados à atuação do executivo (administração pública); 3.3 Principais aspectos da segurança jurídica relacionados à atuação do judiciário; 4. Considerações finais; 5. Notas; Referências 


\section{INTRODUÇÃO}

A segurança é indispensável para que as pessoas possam conduzir sua vida de forma autônoma, previamente organizada e com confiança de que o futuro não será tão diferente do presente. Sem segurança impera a desordem, o caos e as frustrações decorrentes, além de inexistir proteção ao arbítrio dos governantes ou daqueles que detém o poder.

A segurança jurídica, por sua vez, significa um mínimo de garantias concedidas aos cidadãos (e aos contribuintes) no e pelo direito. Quando da ocorrência de alterações jurídicas na lei ou na sua interpretação, a segurança jurídica impõe a não ocorrência de grandes rupturas com o direito anterior (por exemplo, a elaboração de regras de transição) para não frustrar expectativas legítimas, que podem e devem ser resguardadas pelo sistema jurídico.

Isso significa que o princípio da segurança jurídica é inseparável dos ideais do Estado Democrático de Direito e se consubstancia em um dos fundamentos da República Federativa do Brasil. Todo ramo do direito possui normas que visam resguardar a segurança jurídica, e a adequada delimitação de sua eficácia e funcionalidade é imprescindível para que o ordenamento jurídico seja considerado estável, previsível e coerente.

Nesse contexto, o objetivo do estudo é analisar o problema da fiscalidade e da tributação à luz da existência de um direito fundamental à segurança jurídica que ampare o contribuinte contra as arbitrariedades praticadas pelo Estado. Busca-se compreender a importância e as formas de manifestação da segurança jurídica - na perspectiva da proteção à confiança -, em especial na relação fisco-contribuinte no âmbito dos poderes constituídos (Legislativo, Executivo e Judiciário).

O método de abordagem utilizado para a realização do trabalho é o dedutivo, porque se parte de premissas gerais para premissas particulares. A técnica de pesquisa é de revisão bibliográfica e jurisprudencial. O procedimento empregado é o monográfico.

O desenvolvimento do artigo ocorrerá em duas etapas. Primeiro, examina-se o princípio da segurança jurídica à luz da dogmática dos direitos fundamentais e sua intrínseca relação com o Estado Democrático de Direito, bem como sua evolução até a perspectiva da proteção à legítima confiança. Depois, analisam-se os principais aspectos dogmáticos e práticos da segurança jurídica relacionados à atuação do parlamento, da administração e do judiciário no âmbito da relação fisco-contribuinte.

\section{SEGURANÇA JURÍDICA COMO ELEMENTO INDISSOCIÁVEL DOS SISTEMAS JURÍDICOS (CIVIL E COMMON LAM) E DO ESTADO DEMOCRÁTICO BRASILEIRO}

A finalidade do direito é a justiça, mas a formulação das normas jurídicas nem sempre tem como escopo principal concretizá-la. A positivação do direito em geral tem como objetivo garantir segurança e certeza na vida social: o direito como instrumento de segurança (SILVA, 2009, p. 15).

A justiça e a segurança são, portanto, os valores que embasam a existência do direito, havendo correspondência entre ambos ("segurança não é renúncia à justiça, mas sua pro- 
moção" - ÁVILA, 2014, p. 673), pois o direito seguro (segurança do direito positivado) nem sempre será justo - como ocorre nos sistemas autoritários. Por outro lado, o direito inseguro será necessariamente injusto, porquanto não assegura ou observa o princípio da igualdade, motivo da procura pelo "direito seguro legítimo, que é aquele que vale para todos." (SILVA, 2009, p. 15).

Isso significa que "a segurança jurídica é, por excelência, um sobreprincípio, ou seja, um conjunto de princípios que operam para realizar um entrelaçamento de outros princípios." (CAVALCANTE, 2009, p. 114). Para Borges (2008, p. 24), "a segurança é, então, como uma bússola a nortear a exegese constitucional e a integração da Constituição Federal pela legislação ordinária rumo à sua efetividade e concretização."

No mesmo sentido, Sarlet (2009, p. 90) enfatiza que a segurança jurídica "passou a ter o status de subprincípio concretizador do princípio fundamental e estruturante do Estado de Direito", sendo "simultaneamente princípio fundamental da ordem jurídica estatal e, para além desta, da própria ordem jurídica internacional."

A sua importância é realçada em época de crise e/ou de mudança de paradigma cultural (CÔRTES, 2008, p. 26). No caso do Estado brasileiro, pode-se afirmar que atualmente se vivenciam ambas as situações. Isso porque há uma crise econômica e ética persistentes e o sistema jurídico está sendo modificado com o objetivo de aproximar o Civil Law brasileiro com o denominado Common Law.

No Civil Law a segurança jurídica e a igualdade eram representadas pelo produto da atuação do parlamento - pelas leis -, já que os expoentes da Revolução Francesa desconfiavam dos juízes, que em geral compactuavam com a manutenção dos privilégios da monarquia absolutista. Essa desconfiança em relação ao judiciário acarretou a ruptura do sistema jurídico, ${ }^{1}$ dando origem à era das codificações excessivas e ao formalismo na interpretação judicial (o juiz apenas declara a vontade da lei ou do legislador, que representa o povo).

Logo, o legislativo era a garantia de segurança jurídica e de igualdade, na medida em que expressava a vontade do povo, o verdadeiro titular do poder de elaborar normas. ${ }^{2}$ Ao juiz cabia apenas observá-la (e não a interpretar), de modo que a atividade judicial era meramente declaratória de uma solução prévia concebida pelo legislador para todos os conflitos.

Por sua vez, o Common Law inglês manteve a sua estrutura inicial, não obstante a Revolução Gloriosa de 1688 ter limitado os poderes do monarca inglês. Não houve a reformulação do direito, mas sim o seu desenvolvimento contínuo. ${ }^{3} \mathrm{~A}$ força dos precedentes (ou das regras jurisprudenciais ${ }^{4}$ ) ainda é a responsável pela preservação da segurança jurídica e da igualdade.

Com efeito, o sistema do Common Law "não relaciona a previsibilidade com o conhecimento da lei, mas sim com a previsibilidade das decisões do Poder Judiciário." (MARINO$\mathrm{NI}, 2016$, p. 98). Nesses moldes, a finalidade do sistema de precedentes judiciais, instituído com o Novo Código de Processo Civil, é inequívoco: unir de forma efetiva a segurança jurídica e a igualdade ${ }^{5}$ para fins da justiça a partir da previsibilidade das decisões judiciais. 
Disso decorre que a segurança jurídica é intrínseca ao Estado Democrático de Direito. Tem por objetivo, de um lado, garantir a estabilidade do ordenamento jurídico e, de outro, a proteção da legítima confiança, a previsibilidade acerca da atuação do Poder Público (CANOTILHO, 2003, p. 164).

Partindo dessa perspectiva, Estado Democrático de Direito e segurança jurídica podem ser consideradas expressões equivalentes, pois o significado da segunda denota:

\begin{abstract}
1. a existência de instituições estatais dotadas de poder e garantias, assim como sujeitas ao princípio da legalidade; 2 . a confiança nos atos do Poder Público, que deverão reger-se pela boa-fé e pela razoabilidade; 3 . a estabilidade das relações jurídicas, manifestada na durabilidade das normas, na anterioridade das leis em relação aos fatos sobre os quais incidem e na conservação de direitos em face da lei nova; 4. a previsibilidade dos comportamentos, tanto os que devem ser seguidos como os que devem ser suportados; 5 . a igualdade na lei e perante a lei, inclusive com soluções isonômicas para situações idênticas ou próximas. (BARROSO, 2009, p. 139-140).
\end{abstract}

Do mesmo modo, Couto e Silva (2017, p. 02) afirma que "a noção de segurança jurídica é conatural e, pois, indissociável da própria noção de direito, só existindo direito onde existe segurança jurídica."

Tais considerações conferem à segurança jurídica o status de princípio estruturante da Constituição Federal de 1988, tanto que seu conceito representa uma multiplicidade de ideais, dimensões e aspectos a serem conjunta e equilibradamente considerados:

\footnotetext{
[...] segurança jurídica como sendo uma norma-princípio que exige, dos Poderes Legislativo, Executivo e Judiciário, a adoção de comportamentos que contribuam mais para a existência, em benefício dos cidadãos e na sua perspectiva, de um estado de confiabilidade e de calculabilidade jurídica, com base na sua cognoscibilidade, por meio da controlabilidade jurídico-racional das estruturas argumentativas reconstrutivas de normas gerais e individuais, como instrumento garantidor do respeito à sua capacidade de - sem engano, frustração, surpresa e arbitrariedade - plasmar digna e responsavelmente o seu presente e fazer um planejamento estratégico juridicamente informado do seu futuro. (ÁVILA, 2016, p. 286).
}

Os princípios são normas que têm o objetivo de ordenar a realização de algo na maior medida possível, observando-se, contudo, as possibilidades fáticas e jurídicas existentes (ALEXY, 2008, p. 588). Assim, na aplicação de um princípio, deve-se tentar atingir o seu grau máximo, sem que isso afaste ou iniba de forma demasiada outro princípio de mesma hierarquia. Por outro lado, "as regras [...] são normas que pretendem produzir efeitos já definidos e delimitados em seu comando, e aplicáveis a um conjunto de situações que pode ser previamente identificado, apenas tendo em conta o dispositivo normativo." (BARCELLOS, 2002, p. 77).

$\mathrm{Na}$ colisão de princípios não se afasta um dos princípios do sistema, pelo contrário, procura-se uma otimização. Os princípios são, então, comandos a serem otimizados (ALEXY, 2000, p. 300). Já o conflito de regras se define pela regra do tudo ou nada. Normalmente "um conflito de regras somente pode ser solucionado se se introduz, em uma das regras, uma cláusula de exceção que elimine o conflito, ou se pelo menos uma das regras for declarada inválida." (ALEXY, 2008, p. 92). Portanto, se não há exceção na própria regra (cláusula de exceção), o conflito entre regras induz a declaração de invalidade de uma delas.

A partir desse panorama, muito do que se chama de princípio deveria ser chamado 
de regra. Um exemplo está inserido na Constituição Federal, no artigo 150: "Sem prejuízo de outras garantias asseguradas ao contribuinte, é vedado à União, aos Estados, ao Distrito Federal e aos Municípios: I - exigir ou aumentar tributo sem lei que o estabeleça; [...]".

Há uniformidade em denominar tal norma como princípio da legalidade, ${ }^{6}$ ainda que o mandamento inserido não expresse um comando a ser otimizado ou observado na maior medida possível. O "princípio" da legalidade é uma genuína regra porque a consequência jurídica da exigência de tributo sem lei já se encontra definida, ou seja, o resultado da decisão judicial não depende da ponderação entre princípios conflitantes. O legislador constituinte já fez a ponderação (atribuindo maior peso ao princípio da segurança jurídica) e o resultado é a regra que diz que é vedado exigir ou aumentar tributo sem lei correspondente.

Assim, embora seja possível relacionar inúmeras concepções de segurança jurídica, não há dúvida de que ela sugere uma garantia mínima aos jurisdicionados ou uma promoção na maior medida do possível, pois se trata de um princípio fundamental do ordenamento.

\title{
2.1 A EVOLUÇÃO DO PRINCÍPIO DA SEGURANÇA JURÍDICA COMO PROTEÇÃO Å CONFIANÇA
}

A segurança jurídica é inseparável da ideia ou dos ideais do Estado Democrático de Direito e se consubstancia em um dos fundamentos da República Federativa do Brasil (mencionada expressamente no preâmbulo e no caput do art. $5^{\circ}$ da CF/88). Tem por objetivo garantir a estabilidade do ordenamento jurídico e a proteção da legítima confiança (previsibilidade da manifestação do Poder Público). Como bem sintetiza Couto e Silva:

\begin{abstract}
Seja, porém, qual for o sentido que se possa dar à expressão segurança jurídica, a garantia que ela sugere é a de que, ainda que a vida seja essencialmente mutável, será sempre necessário - no que diz com a ordem jurídica ou com os direitos individuais - que tanto quanto possível, uma parte do hoje seja igual ao ontem ou uma fração do amanhã seja igual ao hoje, de tal sorte que a cadeia do tempo se constitua sempre com esse quid de permanência do velho no novo. É isto que empresa coerência, previsibilidade, calculabilidade e autoridade ao conjunto de normas jurídicas, ao mesmo tempo que infunde tranquilidade aos indivíduos, quer com relação aos compromissos e vínculos jurídicos que estabeleceram no passado e que esperam sejam mantidos, quer no tocante aos planos que elaborarão, no futuro, na condução de suas vidas. (COUTO e SILVA, 2017, p. 02).
\end{abstract}

Em razão destas circunstâncias, Bankowski (2007, p. 181) afirma que "o ponto central do Estado de Direito é que, por ser prospectivo, nos permite prever o que acontecerá e, assim, nos permite organizar nossas vidas antecipadamente."

Partindo-se de um recorte histórico, fixando-se o olhar no período moderno, pode-se afirmar que no Estado Absolutista a segurança jurídica era uma garantia fictícia, quase inexistente. Tudo dependia da atuação do monarca, que pouca ou nenhuma limitação possuía, não sendo diferente a situação em episódios de regimes autoritários do século XX.

Nesse contexto, a segurança jurídica no tocante ao direito público (relação cidadão-poderes ou pessoas-Estado) também não existia substancialmente ou juridicamente (no sentido de ser um direito subjetivo exercitável). Concretizava-se somente nas relações entre indivíduos, isto é, exclusivamente no campo do direito privado (COUTO E SILVA, 2017, p. 02-03). 
Apenas a perspectiva estática do conceito de segurança jurídica era adotada, quer dizer, as modificações no ordenamento não podiam interferir nas situações jurídicas consolidadas pelo direito adquirido, ato jurídico perfeito e coisa julgada. Esse regulamento consta, na Constituição de 1988, como garantia fundamental contra a atuação do Legislativo (art.

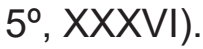

Portanto, foi no domínio do direito privado que o comportamento dos sujeitos de direito passou a assumir grande relevância a ponto de se institucionalizar nos ordenamentos jurídicos o instituto (princípio) da boa-fé objetiva. No sistema jurídico nacional foi positivado pela primeira vez no Código Civil de 2002 (art. 113 e 142).

A apreciação do comportamento dos sujeitos de direito com reflexos jurídicos relevantes foi se incorporando gradualmente e assumindo destaque também no âmbito do direito público, seja nas relações contratuais (contratos administrativos) firmadas pelos entes estatais, seja no tocante à sua responsabilidade extracontratual (COUTO E SILVA, 2017, p. 04).

O processo de mudança - ou de incorporação de um instituto nitidamente privado ao direito público - foi vagaroso. Iniciou-se com a excepcional possibilidade de manutenção de atos administrativos inválidos ou ilegais, em meados do século $\mathrm{XX}$, na Europa. O leading case ocorreu na Alemanha no início da década de 1960: a uma viúva foi prometido que a mudança de domicílio de Berlim Oriental para Ocidental acarretaria o recebimento de pensão pela morte de seu marido (servidor público). Após um ano do recebimento do benefício, ele foi cancelado sob o fundamento de que havia vício de competência na concessão.

Embora o vício tenha se confirmado, o Superior Tribunal de Berlim manteve o benefício ao atribuir eficácia jurídica ao princípio constitucional da proteção da confiança. Essa tese jurídica foi aceita pelo Tribunal Federal Constitucional alemão em 1961, gerando o que foi denominado de a "marcha triunfal" de tal princípio, cuja importância foi sedimentada somente na década de 1970, gerando amplo desenvolvimento literário sobre o tema (COUTO E SILVA, 2017, p. 06).

No Brasil, somente no ano de 1999 foram editados regramentos jurídicos que enfatizaram a segurança jurídica sob o prisma da proteção da confiança no direito público: a primeira relacionada ao processo administrativo federal (art. $2^{\circ}$ e 54 da Lei 9784/99); a segunda concernente ao controle concentrado de constitucionalidade (art. 27 da Lei 9868/997); por fim, a lei que regulamentou a arguição de descumprimento de preceito fundamental (art. 11 da Lei 9882/99).

As decisões judiciais relevantes sobre o tema foram proferidas em 2003 e 2004, tendo como relator o Min. Gilmar Mendes (MC 2.900, MS 24.268 e MS 22.357), circunstância que rompeu os paradigmas estabelecidos pelas conhecidas Súmulas 473 e 346 do Supremo Tribunal Federal (COUTO e SILVA, 2017, p. 09).

\subsection{O CONTEÚDO DA “PROTEÇÃO DA LEGÍTIMA CONFIANÇA” NA RELAÇÃO FISCO-CONTRIBUINTE}

Atualmente na Alemanha, a partir das decisões do Tribunal Constitucional Federal, segurança jurídica é sinônimo de proteção da confiança, o mesmo ocorrendo na jurisprudência 
do Supremo Tribunal Federal. ${ }^{8}$ É importante também registrar o fato de que a perspectiva da proteção da confiança foi adotada e delimitada no âmbito da Comunidade Europeia, a saber:

\begin{abstract}
Sucesso semelhante teve o princípio da proteção à confiança no direito da Comunidade (hoje União) Europeia, cuja Corte de Justiça acolheu-o como "regra superior de Direito" e "princípio fundamental do direito comunitário", abrangendo vasta gama de situações, pertinentes (i) à invalidação de atos administrativos ilegais, (ii) à mudança de regime jurídico sem prévia adoção de medidas transitórias, (iii) à responsabilidade extracontratual do Estado, no campo do direito administrativo econômico, pela ruptura de promessas firmes e compromissos assumidos, como, por exemplo, na concessão de subvenções públicas, bem como (iv) à função pública comunitária, especialmente nos casos de anulação de atos administrativos geradores de benefícios para seus destinatários de boa-fé. (COUTO e SILVA, 2017, p. 07).
\end{abstract}

Conforme Martins-Costa ${ }^{9}$ (2004, p. 112), a primeira decisão proferida pelo Min. Gilmar Mendes, embora em sede de tutela provisória, acarretou uma ressignificação do princípio da segurança jurídica. Houve uma renovação (ou uma transformação) do seu âmbito de normatividade. A segurança jurídica, vista como garantia de estabilidade e legalidade (perspectiva estática), passou a significar também o princípio da confiança legítima (perspectiva dinâmica).

O novo significado (ou nova atribuição de conteúdo normativo) da segurança jurídica no tocante à relação entre administração pública e seus administrados ${ }^{10}$ estabelece a atuação em duas frentes: segurança jurídica como estabilidade e como expectativa legítima do cidadão em certo comportamento estatal. Não é, portanto, um fundamento "geral e abstratamente perceptível, a confiança só é avaliável na concretude das circunstâncias." (COSTA, 2004, p. 115).

Daí a razão de se afirmar que há um novo conteúdo (uma nova roupagem, um novo significado) da segurança jurídica e também do Estado de Direito, que é o estado de confiança. Com efeito, é absolutamente falho um ordenamento jurídico que desconsidere o fator "confiança", na medida em que é essencial à realização da justiça material (COSTA, 2004, p. 116).

Por conseguinte, na relação fisco-contribuinte, o princípio da segurança jurídica é instrumento de realização dos ideais de liberdade, igualdade e de dignidade. ${ }^{11}$ Ele evidencia que a proteção da legítima confiança não se limita às mudanças legislativas, mas também às mudanças administrativas e jurisprudenciais, as quais afetam a própria noção de Estado de Direito. Essa é a perspectiva dogmática que alicerça o próximo tópico.

\title{
3. PROTEÇÃO DA LEGÍTIMA CONFIANÇA, OS PODERES CONSTITUIIDOS E A RELAÇÃO FISCO-CONTRIBUINTE
}

Todo ramo do direito possui normas que visam resguardar a segurança jurídica em sua dimensão estática e dinâmica. A adequada delimitação de sua eficácia e funcionalidade é imprescindível para que o ordenamento jurídico de um determinado Estado seja considerado estável, previsível e coerente.

A aplicação do princípio da segurança jurídica, no entanto, é realizada de modo diferenciado ou individualizado para cada ramo do direito, a depender das particularidades do objeto da relação jurídica. Além disso, é possível falar em escalonamento na sua importância 
a partir dos diferentes ramos do direito. No direito tributário, a importância de sua observância é notória, pois a relação tributária, conforme Teodorovicz (2016, p. 68), evidencia o tênue equilíbrio de forças, na medida em que ordinariamente pende "para o lado do governo (ou do monarca, ou do soberano) em detrimento do contribuinte, ou súdito ou cidadão."

Logo, o princípio da segurança jurídica no âmbito da relação jurídico-tributária possui um atributo especial, no sentido de que as normas do Sistema Tributário Nacional têm um caráter essencialmente protetivo ao contribuinte (ou aos direitos fundamentais do contribuinte). Essas normas tributárias específicas garantem:

\begin{abstract}
[...] a inteligibilidade do Direito pela determinabilidade das hipóteses de incidência (regra da legalidade e sistemas de regras de competência), a confiabilidade do Direito pela estabilidade no tempo (regra de reserva de competência para lei complementar regular prescrição e decadência), pela vigência (regra de proibição de retroatividade) e pelo procedimento (regras expressas de abertura do subsistema tributário a direitos e a garantias nele não previstos, como é o caso das proteções ao direito adquirido, à coisa julgada e ao ato jurídico perfeito), e a calculabilidade do Direito pela não-surpresa (regra da anterioridade). (ÁVILA, 2016, p. 687).
\end{abstract}

Quanto à atuação dos poderes, no sentido de dever de assegurá-las:

[...] pelo Poder Legislativo, porque o Sistema Tributário contém regras de competência a ele destinadas e princípios que delimita, formal e materialmente, o exercício do poder de tributar, assim como prevê as regras de legalidade, de anterioridade e de irretroatividade, que impõem a esse Poder o dever de criar obrigações tributárias de determinado modo e com determinada eficácia; pelo Poder Executivo, porque o referido Sistema contém tanto normas sobre a atuação estatal, especialmente os princípios dirigidos à Administração Pública, quanto normas que, indiretamente, vinculam a atuação administrativa ao disposto em lei, daí derivando a eficácia executiva dos regulamentos e a limitação material para a instituição de obrigações acessórias; pelo Poder Judiciário, considerando que o mencionado Sistema estabelece princípios processuais igualmente aplicáveis ao processo administrativo e ao processo judicial, bem como prevê garantias que poderão ser usadas preventiva ou repressivamente na defesa dos contribuintes, como é o caso do mandado de segurança em matéria tributária. (ÁVILA, 2016, p. 700).

Isso significa questionar o problema da fiscalidade e da tributação no Estado Democrático de Direito também à luz da existência de um direito fundamental à segurança jurídica que ampare o contribuinte (sujeito de direito) contra as arbitrariedades praticadas pelos Poderes constituídos.

\title{
3.1 PRINCIPAIS ASPECTOS DA SEGURANÇA JURÍDICA RELACIONADOS À ATUAÇÃO DO LEGISLATIVO (PARLAMENTO)
}

A CF/1988 é permeada por normas jurídicas que denotam uma clara preocupação com a proteção à segurança jurídica do contribuinte. Conforme Porto (2016, p. 148), "basta compulsar o texto constitucional para perceber que a criação de um ambiente de segurança jurídica é quase uma obstinação do constituinte."

Em verdade, o princípio da segurança jurídica é construído sobre duas bases: primeiro, por meio da interpretação dedutiva do princípio maior do Estado de Direito (art. $1^{\circ}$ ); depois, pela interpretação indutiva de outras regras constitucionais, em especial do direito adquirido do ato jurídico perfeito e da coisa julgada (art. $5^{\circ}, \mathrm{XXXVI)}$, assim como das regras relacionadas ao direito tributário especificamente (TEODOROVICZ, 2016, p. 82). 
De fato, em matéria tributária, a concretização da segurança jurídica se dá pelas normas de irretroatividade tributária (art. 150, III, a, CF), anterioridade tributária (art. 150, III, b e c CF), capacidade contributiva, vedação ao confisco (art. 150, IV, CF) e legalidade (art. 150, I, CF).

O caráter de "regra jurídica" de tais normas torna o sentido dos comandos definitivos e não suscetíveis de ponderação. Em que pese sua importância, a abordagem delas não é o escopo do estudo, com exceção da legalidade. Ela é central para o Direito Tributário, para a concretização de um sistema permeado pela segurança jurídica, em especial na acepção de proteção à confiança.

De acordo com Paulsen (2006, p. 88), a legalidade não se restringe à reserva legal, mas também à instituição dos critérios da norma tributária, como a tipicidade fechada, os critérios determinados, a necessidade de completude e a necessidade de densidade. Tampouco se restringe à exigência de que somente por lei formal é possível aumentar o tributo, pois ela incide também na definição dos sujeitos, do objeto e dos aspectos inerentes à norma matriz de Direito Tributário (aspecto material, espacial, temporal, pessoal e quantitativo).

É imprescindível, assim, que o contribuinte tenha a certeza quanto à lei tributária impositiva em abstrato e à aplicação do direito. Como se vê, "a legalidade é uma manifestação da necessidade de segurança, continuidade, previsibilidade e estabilidade das normas em matéria de tributos." (TEODOROVICZ, 2016, p. 66).

A lei que institui a norma tributária impositiva deverá conter os aspectos indispensáveis capazes de determinar o surgimento e o conteúdo da obrigação tributária, ou seja, "não há possibilidade de qualquer delegação de competência legislativa ao Executivo." (PAULSEN, 2006, p. 89).

No tocante à proteção à mudança legislativa, Teodorovicz é preciso:

\begin{abstract}
Também se pode analisar a segurança jurídica em perspectiva dinâmica e intertemporal, com vistas ao passado, no que se refere à imutabilidade (das normas jurídicas ou do direito) e à confiabilidade (estabilidade na mudança, exigência de um ordenamento jurídico protetor de expectativas e garantidor de mudanças estáveis); com vistas ao futuro (previsibilidade - capacidade de antecipar as consequências jurídicas da conduta; ou calculabilidade - elevada à capacidade de prever as consequências jurídicas de atos ou fatos pela maioria das pessoas). (TEODOROVICZ, 2016, p. 81).
\end{abstract}

Nesse contexto, Paulsen (2006, p. 113) afirma que "a segurança jurídica, enquanto certeza do direito, implica proteção contra inovações legislativas que impliquem a alteração gravosa dos efeitos jurídicos relativos a fatos já ocorridos." É dizer: o contribuinte não pode ser surpreendido pelo legislador, devendo ser preservada a proteção à confiança.

O contribuinte é o principal destinatário das normas jurídico-tributárias e o seu comportamento decorre não só do conhecimento das prescrições normativas como também da garantia de atuação adequada dos demais Poderes para fins de planejamento dos seus atos. Isso se aplica tanto para o contribuinte-cidadão como para o contribuinte-empresário, circunstância que repercute na forma de elaboração das normas, que devem utilizar uma linguagem capaz de ser compreendida pelo contribuinte (e não apenas por seus advogados e contadores), com divulgação adequada. Essa é mais uma das perspectivas trazidas pela 
segurança jurídica.

\subsection{PRINCIPAIS ASPECTOS DA SEGURANÇA JURÍDICA RELACIONADOS À ATUAÇÃO DO EXECUTIVO (ADMINISTRAÇÃO PÚBLICA)}

O Executivo tem como função principal concretizar o regramento tributário, isto é, organizar o procedimento para fins de arrecadação dos tributos instituídos pela Constituição e disciplinados em lei. Incumbe-lhe, na realização de tal atividade, observar o conteúdo da segurança jurídica em sua perspectiva estática (princípios constitucionais tributários) e dinâmica (relação com o contribuinte).

Nessa perspectiva, há um abismo entre teoria e prática: "é com indiscutível perplexidade que se observa que a relação entre Fisco e contribuinte, tal qual preconizada pela Constituição, possui um perfil, e a relação observada no cotidiano possui outro, absolutamente diverso." (PORTO, 2016, p. 147). Isso decorre também da grande dificuldade da legislação tributária brasileira (aspecto relacionado à atuação do Parlamento).

De todo modo, é importante ressaltar os principais aspectos relacionados à segurança jurídica na administração estatal: (a) o dever de colaboração, comunicação e orientação; (b) o dever fundamental à boa administração; (c) a impossibilidade de comportamentos surpreendentes e contraditórios.

O dever de colaboração está intimamente ligado ao dever de comunicação:

O resultado é que a Administração, ao se "comunicar" melhor com os cidadãos,
renova as suas estruturas tradicionais (muitas vezes paralisada pela insufici-
ência de informações, fechada em si mesma, trabalhando em compartimentos
separados e estanques, agarrada em rotinas) e se torna mais eficiente. Assim,
a Administração prestadora encontra sua eficácia não só nos comandos autori-
tários, mas, principalmente, no convencimento persuasivo dos cidadãos. (BOR-
GES, TABORDA, 2015, p. 253).

As normas constitucionais evidenciam a existência de um modelo de conduta estatal esperado, voltado a orientar sadiamente o convívio entre a Administração e sociedade. Em outras palavras, a Administração tem o compromisso de atuar de forma proba e consentânea com a ética, sendo certo que os atos estatais geram aos cidadãos expectativas legítimas que merecem atenção e respeito do Poder Público (PORTO, 2016, p. 154-155).

Assim, a Administração Pública deve colaborar com o contribuinte, seja comunicando, seja orientando. Imperioso é desvincular-se da ideia de que o fisco está em um polo e o contribuinte em outro. É necessário superar o dogma de que os interesses são diametralmente opostos. É exatamente por isso que "para ser possível a convivência social, é preciso um mínimo de confiança e previsibilidade." (CAVALCANTE, 2009, p. 116).

Por outro lado, "o dever de orientar o contribuinte se sobrepõe ao dever de autuar." (BORGES, 2008, p. 21). A divergência de interpretação não pode ser considerada normal, como habitualmente ocorre. A própria dificuldade da legislação tributária e, em consequência, a existência de opiniões interpretativas diversas, revela a necessidade do dever de orientar. 
Esse fato torna o dever de orientar ainda mais importante, porque sobrepõe a máxima de que o fisco busca apenas autuar para arrecadar: "o dever-poder de autuar não é, pois, absoluto e ilimitado." (BORGES, 2008, p. 20). Isso traz repercussões inclusive na seara penal. Muitas vezes o contribuinte antes de receber a devida orientação é autuado administrativamente e indiciado penalmente.

Convém lembrar a ressalva de Couto e Silva (2017, p. 21), "segurança jurídica evidentemente não elimina a autoridade do Estado, mas a limita e torna por certo mais justas as relações que ele estabelece com os indivíduos, os quais passam a viver mais tranquilos no seu espaço de liberdade." Portanto, se é verdade que "fisco e contribuinte estão vinculados de forma umbilical, dada a mútua dependência que notabiliza esta relação", parece evidente que há "direito fundamental à boa administração." (PORTO, 2016, p. 157 e 151).

Nesse contexto, outro aspecto do princípio da segurança jurídica confirma: "não são toleradas ações tomadas de surpresa contra os contribuintes, que haverão de reclamar a garantia de previsibilidade e estabilidade na atuação estatal." (RODRIGUES, 2016, p. 61). As legítimas posições jurídico-objetivas necessitam preservação em razão de mudanças políticas ou normativas que repercutem na atuação da Administração.

Da mesma forma, a modificação do entendimento da Administração (seja qual for a razão) não pode ter efeitos retroativos (o que revela o dever de colaboração), razão pela qual vige a orientação do fato gerador (PORTO, 2016, p. 172). Há de se preservar a segurança diante da mudança.

Em resumo, não se deve surpreender o contribuinte. A Administração Pública não é inimiga do contribuinte. O ideal da boa administração compele a uma atuação pautada pela segurança jurídica, protegendo a legítima confiança a partir da própria forma de agir.

\subsection{PRINCIPAIS ASPECTOS DA SEGURANÇA JURÍDICA RELACIONADOS À ATUAÇÃO DO JUDICIÁRIO}

No que diz respeito ao Poder Judiciário, serão destacados, dentre vários temas possíveis, a (a) mudança jurisprudencial e a (b) coisa julgada e sua relativização - (art. 525, $\S 15$, do NCPC).

No tocante ao primeiro ponto, exemplifica-se com um relato infelizmente cotidiano: determinado contribuinte, observando uma posição jurisprudencial sedimentada dos Tribunais Superiores, organiza a sua atuação futura nesse sentido. Não obstante, é alvo de atuação da administração, que mantém a sua forma de agir a despeito de o Judiciário não Ihe dar razão.

A questão, então, é judicializada, e após alguns anos há uma mudança jurisprudencial. O contribuinte é obrigado a pagar quantias vultosas, além das pesadas multas ou outras sanções jurídicas, por ter observado aquilo que decidiam - pacificamente, frise-se - os Tribunais.

A estabilidade não se traduz apenas na continuidade do direito legislado e sua observância pelo Executivo. Implica também continuidade e respeito às decisões judiciais, 
ou melhor, aos precedentes judiciais, significando que, para fins da perspectiva estática e dinâmica da segurança jurídica, pouco adianta ter legislação estável e frenética alternância das decisões judiciais. Os tribunais devem dar sentido e estabilidade ao direito e às relações jurídicas, pois, do contrário, se transformam em mais uma das tantas fontes de incertezas e surpresas que assombram os brasileiros.

A manifestação de Ávila sobre os problemas decorrentes do desempenho judicial em relação à segurança jurídica é precisa:

\begin{abstract}
Em virtude, no entanto, das causas sociais e jurídicas expostas na parte introdutória deste trabalho, também a jurisdição tem causado problemas de congnoscibilidade, em virtude da falta de fundamentação adequada das decisões ou, mesmo, da existência de divergências entre decisões, órgãos ou tribunais; de confiabilidade, em razão da modificação jurisprudencial de entendimentos anteriormente consolidados com eficácia retroativa inclusive para aqueles que, com base no entendimento abandonado, praticaram atos de disposição dos seus direitos fundamentais; e de calculabilidade, pela falta de suavidade das alterações de entendimento ou, mesmo, pela ausência de coerência na interpretação do ordenamento jurídico. (Ávila, 2016, p. 179).
\end{abstract}

Então, a maior problemática enfrentada pelo contribuinte no Poder Judiciário é a existência de decisões diferentes para casos idênticos, bem como a constante mudança jurisprudencial, geradora de insegurança que abala a confiança no próprio sistema judicial.

Outro ponto que merece destaque é a regulamentação, pelo novo CPC, da chamada relativização/desconsideração da coisa julgada - art. 525, §§12 a 15, com o mesmo regramento na impugnação apresentada pela Fazenda Pública - art. 535, $\S \S 5^{\circ}$ a $8^{\circ}$.

A coisa julgada diz respeito à estabilidade das relações sociais via judiciário (pacificação social pela eliminação definitiva da controvérsia) e suscita debates que vão desde a sua definição normativa (princípio ${ }^{12}$ ou regra ${ }^{13}$ ) até as decisões que ensejam sua intangibilidade.

Sobre este último aspecto, os $\S 12$ a 14 do art. $525^{14}$ do NCPC visaram sanar algumas controvérsias que decorriam da redação constante no CPC/73 (art. 475-L, $\S 1^{\circ}$, e art. 741); com tal propósito consta que a decisão do Supremo Tribunal Federal pode ter sido proferida em controle difuso ou em controle concentrado (§12), assim como deve ser anterior ao trânsito em julgado da decisão exequenda (§14) e é passível de modulação dos efeitos no tempo pelo próprio STF (§13), em atenção à segurança jurídica.

Reichelt (2016, p. 173-174) refere que uma abordagem sistemática permitiria a desconsideração da coisa julgada sempre que a sentença exequenda destoasse das demais espécies constantes do rol do art. 927, pois "também elas acabam por se impor de maneira vinculante."

A viabilidade de tal proposição depende da interpretação da Súmula 343 do STF. ${ }^{15}$ Se o critério for o da mera inexistência de controvérsia ao tempo da sentença exequenda (sem o concomitante emprego dos adjetivos de violação grave, aberrante e intolerável quanto à interpretação atribuída na decisão objeto de rescisão), a pacificação da jurisprudência por uma das hipóteses constantes do rol do art. 927 ensejará não só o ajuizamento como a procedência da ação rescisória fundada no art. 966, V, do CPC/15. A ação rescisória tornar-se-á em mero rito obrigatório, circunstância que reforçaria a possibilidade jurídica de se estender 
o disposto no art. 525, §12, às demais hipóteses previstas no art. 927 do NCPC.

Por outro lado, o §15 do art. 525 do CPC/2015 dispõe que, se a decisão de inconstitucionalidade ocorrer em momento posterior ao trânsito em julgado, ao vencido será possível propor ação rescisória no prazo de dois anos contados do trânsito em julgado da decisão proferida pelo Supremo Tribunal Federal. ${ }^{16}$ Isso significa a inexistência de prazo, pois o termo inicial depende de um evento futuro e incerto.

A referida regra tem sofrido questionamentos quanto à sua constitucionalidade material, pois "acaba com o controle difuso de constitucionalidade dos tribunais e dos juízes", além de "colocar a coisa julgada sob condição ou em estado de provisoriedade" e, ainda, fundar-se a ação rescisória "na retroatividade do direito superveniente", em manifesta afronta ao art. $5^{\circ}, \mathrm{XXXVI}$, da CF/88 (MARINONI, 2016, p. 275-307).

O destino da ação rescisória ajuizada com amparo no art. 966, V, também dependerá da interpretação da Súmula 343 do STF. Caso mantido o entendimento de que não há interpretação controvertida de norma constitucional ${ }^{17}$ e, assim, ser cabível ação rescisória ainda que a decisão rescindenda tenha se baseado em interpretação controvertida anterior à orientação fixada pelo STF, o julgamento terá de ser necessariamente de procedência.

Isso implica que na relação fisco-contribuinte uma eventual decisão do Supremo Tribunal Federal acerca da constitucionalidade ou inconstitucionalidade de determinada lei ou ato normativo tributário poderá ensejar a desconsideração do título executivo formado em favor do constituinte, ainda que a sentença tenha transitado em julgado há, por exemplo, mais de uma década.

Tal formatação jurídico-processual (art. 525, §15, do NCPC) é inconstitucional, na medida em que a não reiteração de julgados é um princípio básico da coisa julgada, regra jurídica que deriva do princípio da segurança jurídica, que, por sua vez, tem assento no Estado Democrático de Direito. Importante, nesse aspecto, é referir os ensinamentos de Nieva Fenoll:

O princípio básico de que parte o conceito de coisa julgada é o seguinte: os juízos só devem realizar-se uma única vez. Deste princípio se deriva que a coisa julgada consiste em uma proibição de reiteração de juízo. Esse foi o postulado da época de HAMMURABI, esse era o postulado no período romano, e esse é e seguirá sendo o postulado de que a coisa julgada partirá em todo caso. A razão disso é muito evidente e pode resumir-se deste modo: a segurança jurídica requer que sobre cada assunto somente se possa decidir uma única vez. A jurisdição existe para dar estabilidade e segurança às relações humanas conflitivas. Se hoje se determinou que existe um fato delitivo, não é aceitável que amanhã o mesmo Juiz que proferiu a sentença, ou qualquer outro juiz, diga que esse fato nunca existiu, simplesmente porque, nesse caso, os riscos de entrar em uma total corrupção e falta de seriedade que, sem dúvida, acabariam com ele [...] Por essa razão, que se constata sem dificuldade, a coisa julgada permite garantir essa necessária seriedade nas relações jurídicas, seriedade que não é senão um corolário da segurança jurídica. Assim, a coisa julgada impede que um mesmo litígio seja instaurado duas vezes, tentando-se ganhar em uma segunda oportunidade o que já foi perdido. Ou seja, a existência da coisa julgada contribui para conjurar a desfaçatez dos litigantes para com seus adversários e a própria Justiça. Se não existisse, qualquer cidadão estaria tentando que seja declarado culpado aquele que já foi considerado inocente. Ou procurando ganhar sub-repticiamente em um segundo processo aquilo que não pôde obter no primeiro, ou também buscando recuperar o que foi perdido em um processo 
Tais reflexões demonstram como é delicado relativizar ou desconsiderar os institutos que salvaguardam a segurança jurídica. Com o pretexto de dar uma maior importância à decisão do Supremo Tribunal Federal, atinge-se o núcleo do princípio da segurança jurídica (estabilidade das relações sociais e proteção da legítima confiança).

\section{CONSIDERAÇÕES FINAIS}

A segurança jurídica é um princípio estruturante do Estado Democrático de Direito, atuando em conjunto com o princípio da igualdade. Inexiste justiça na vida social sem a união desses dois valores fundamentais no direito institucionalizado dos sistemas jurídicos (Common Law e Civil Law). Segurança jurídica e igualdade confundem-se, portanto, com a própria noção ou conceito de direito.

O princípio da segurança jurídica, assim como o direito, encontra-se em constante evolução para fins de adaptação às mutações sociais. Atualmente, sua atuação repercute em duas dimensões: a) segurança jurídica como estabilidade do ordenamento jurídico (dimensão estática), com resguardo das situações jurídicas consolidadas como o respeito à coisa julgada, ao ato jurídico perfeito e ao direito adquirido; b) segurança jurídica como proteção à legítima confiança ou à boa-fé objetiva (dimensão dinâmica), cuja implicação principal é a previsibilidade de determinados comportamentos por parte dos sujeitos de direito, notadamente do Poder Público.

Para que o direito fundamental à segurança jurídica tenha funcionalidade prática, a adequada atribuição de sua eficácia é imprescindível para a estabilidade, previsibilidade e coerência do ordenamento jurídico. No entanto, sua repercussão não é uniforme a todos os ramos do direito, pois dependerá das particularidades do objeto da relação jurídica. No âmbito jurídico-tributário, a segurança jurídica possui grande força normativa - um atributo especial -, funcionando como um verdadeiro trunfo dos contribuintes em face dos Poderes constituídos, protegendo-os de alterações legislativas, administrativas e jurisprudenciais arbitrárias.

É, nesses moldes, tarefa do Poder Legislativo formular regras gerais que não afrontem a segurança jurídica, sendo notória a formulação de que "a lei não prejudicará o direito adquirido, o ato jurídico perfeito e a coisa julgada." (art. $5^{\circ}, \mathrm{XXVI}$, da CF/88). Por sua vez, a concretização da segurança jurídica no tocante à matéria tributária encontra-se disciplinada principalmente no art. 150 da CF/88, com as regras concernentes à legalidade, irretroatividade e anterioridade tributárias, além da capacidade contributiva e da vedação ao confisco.

A legalidade tributária (art. 150, I, da CF/88) assume destaque. Além de o contribuinte não poder ser surpreendido com alterações que afetem a legítima confiança quanto a fatos já ocorridos, ele deve ter certeza (estabilidade e previsibilidade) quanto à lei tributária em abstrato e à sua aplicação concreta. Além disso, o parlamento deve utilizar linguagem que possibilite ao contribuinte (e não somente a seus advogados e contadores) compreender adequadamente as regras jurídicas, bem como divulgar adequadamente as modificações ocorridas na legislação tributária. 
À Administração Pública incumbe observar os princípios que lhe são dirigidos para que a sua atuação não afronte os direitos materiais e processuais dos cidadãos. Ela tem o dever de colaborar, comunicar e orientar o contribuinte sobre as nuances do regramento tributário. Tais deveres são pressupostos ao dever de autuação tributária. Além disso, emerge o dever fundamental de se promover uma boa administração e de evitar comportamentos surpreendentes e contraditórios, sobretudo no tocante às modificações de interpretação da legislação tributária.

Também ao Judiciário incumbe observar as dimensões estática e dinâmica da segurança jurídica, com especial ênfase à previsibilidade da atuação judicial. A estabilidade que decore da segurança jurídica não diz respeito apenas à continuidade e observância do direito positivado, mas sim à continuidade e ao respeito aos precedentes judiciais. De nada adianta o sistema jurídico manter estável a legislação se há frenética alternância de decisões (ou interpretações) judiciais sobre a mesma questão. Constantes mudanças jurisprudenciais e decisões diferentes para casos idênticos abalam a confiança no Judiciário e na própria existência de um sistema judicial.

O tema da relativização da coisa julgada é extremamente delicado. Com o pretexto de se atribuir maior importância às decisões do Supremo Tribunal Federal, a disciplina constante do art. 525, §15, e do art. 535, §8, do Novo Código de Processo Civil afronta o núcleo do princípio da segurança jurídica (estabilidade das relações sociais e proteção da legítima confiança). Isso porque tais previsões afetam a finalidade da coisa julgada de pacificação social pela eliminação definitiva da controvérsia jurídica, bem como vulneram o seu próprio conceito de proibição de reiteração de julgados.

As considerações acima evidenciam que a evolução das relações sociais implica necessariamente o aperfeiçoamento constante do direito. Nessa perspectiva, a dimensão dinâmica do princípio da segurança jurídica incide especialmente na relação jurídico-tributária, circunstância que vem exigindo a superação de dogmas e, assim, a modificação da forma de atuar dos poderes Legislativo, Executivo e Judiciário.

A mudança de compreensão da nova funcionalidade do princípio da segurança jurídica não é célere ou instantânea. Ela exige esforços constantes do parlamento, da dogmática jurídica, dos profissionais do direito e também dos agentes públicos envolvidos diretamente na relação tributária. A presente reflexão sobre alguns aspectos que envolvem a segurança jurídica na relação fisco-contribuinte demonstra que, não obstante os avanços ocorridos, há ainda muito espaço para evolução, notadamente na prática administrativa e judicial.

\section{NOTAS}

1. A Revolução Francesa destruiu todo o regime anterior, isto é, alterou toda a estrutura política e todo o sistema jurídico (CAENEGEM, 2010, p. 08-09), instituindo um novo direito a partir da supremacia do Poder Legislativo sobre os demais poderes, em especial sobre o Judiciário.

2. Habermas (1997, p. 297-354) parte do mesmo pressuposto de que o povo é a fonte de toda a legitimação do Direito e do Estado de Direito, enfatizando, no entanto, que tal fonte decorre do poder comunicativo dos cidadãos (teoria discursiva do direito), no sentido de que todos passem a ser ao mesmo tempo 
autores e destinatários do próprio direito, ou seja, das normas que regulam a sua vida em sociedade. Nesse sentido, nem o Judiciário teria a capacidade de superar o poder comunicativo dos cidadãos, motivo pelo qual a interpretação da Constituição não é monopólio dos tribunais.

3. Caenegem (2010, p. 06) aponta como uma característica distintiva do sistema jurídico inglês frente aos demais sistemas europeus (especialmente o francês e o alemão) a inexistência de grandes rupturas, como a ocorrida na França ao tempo da Revolução, motivo pelo qual o presente nunca se encontra totalmente isolado do passado.

4. Bustamante (2012, p. 479-484) afirma que os precedentes geram regras jurisprudenciais como obrigações prima facie.

5. "O valor constitucional tutelado pelo sistema de precedentes das Cortes Supremas não é a unidade do direito, antigo mito através do qual se esconderam instâncias autoritárias dos mais variados gêneros, porém a igualdade, realizada empiricamente mediante a vinculação dos tribunais e juízes ao 'direito' delineado pela Corte, dependente da evolução da vida social, aberto ao dinamismo de um sistema voltado à atuação de princípios fundamentais munidos de inesgotável carga axiológica e atento à devida percepção das diferenças." (MARINONI, 2016, p. 280).

6. Nesse sentido: "a instituição dos emolumentos cartorários pelo Tribunal de Justiça afronta o princípio da reserva legal. Somente a lei pode criar, majorar ou reduzir os valores das taxas judiciárias." (ADI 1.709, rel. min. Maurício Corrêa, julgado em 10-2-2000).

7. Segundo o art. 27 da Lei 9868/99, "ao declarar a inconstitucionalidade de lei ou ato normativo, e tendo em vista razões de segurança jurídica ou de excepcional interesse social, poderá o Supremo Tribunal Federal, por maioria de dois terços de seus membros, restringir os efeitos daquela declaração ou decidir que ela só tenha eficácia a partir de seu trânsito em julgado ou de outro momento que venha a ser fixado". Por outro lado, o art. 23 explicita que "efetuado o julgamento, proclamar-se-á a constitucionalidade ou a inconstitucionalidade da disposição ou da norma impugnada se num ou noutro sentido se tiverem manifestado pelo menos seis Ministros, quer se trate de ação direta de inconstitucionalidade ou de ação declaratória de constitucionalidade". Aqui há uma incongruência. Se seis ministros podem o "mais" (declarar a inconstitucionalidade da lei), por que são necessários dois terços (oito ministros) para fazerem o "menos" (modular efeitos)? A modulação de efeitos é tão somente uma concretização do princípio da segurança jurídica. Se na maior parte das vezes a Lei não retroage, por que a decisão judicial tem o efeito ex tunc como regra?

8. Nesse sentido o MS 27006 AgR (Relator(a): Min. CELSO DE MELLO, Segunda Turma, julgado em 15/03/2016), que estabeleceu a boa-fé e a proteção da confiança como projeções específicas do postulado da segurança jurídica.

9. Pesquisa realizada pela jurista (COSTA, 2004, p. 113) revela que segurança jurídica, para o STF, até agosto de 2003, denotava os "seguintes focos de significação: a) a segurança jurídica está no fundamento do instituto da decadência; b) a segurança jurídica fundamenta o instituto da prescrição; c) a segurança jurídica fundamenta o instituto da preclusão; d) a segurança jurídica fundamenta a intangibilidade da coisa julgada; e) a segurança jurídica é o valor que sustenta a figura dos direitos adquiridos; f) a segurança jurídica é o valor que sustenta o princípio do respeito ao ato jurídico perfeito; g) a segurança jurídica está na base da inalterabilidade, por ato unilateral da Administração, de certas situações jurídicas subjetivas previamente definidas em ato administrativo; $h$ ) a segurança jurídica está na ratio da adstrição às formas processuais; i) a segurança jurídica está na ratio do princípio da irretroatividade da lei, quando gravosa ao status libertatis das pessoas ou afrontosa às situações mais favoráveis, consolidadas pelo tempo ou resguardadas pela lei; [...]; j) a segurança jurídica não impede que lei nova ou ato administrativo dê conformação a situações jurídicas, desde que resguardado o princípio da legalidade, pois não limita de modo absoluto o poder de conformação do legislador".

10. Fruto da obra de Almiro do Couto e Silva, conforme Judith Martins Costa (2004, p. 114). 
11. Segundo Ávila (2016, p. 688-689): "[...] de liberdade, porque quanto maior for o acesso material e intelectual do cidadão-contribuinte relativamente às normas a que deve obedecer, e quanto maior for a sua estabilidade, tanto maiores serão as suas condições de conceber o seu presente e de planejar o seu futuro; de igualdade, porque quanto mais gerais e abstratas forem as normas, e mais uniformemente elas forem aplicadas, tanto maior será o tratamento isonômico do cidadão-contribuinte; de dignidade, porque quanto mais acessíveis e estáveis forem as normas, e mais justificadamente elas forem aplicadas, com tanto mais intensidade se estará tratando o cidadão-contribuinte como um ser capaz de se autodefinir autonomamente, quer pelo respeito presente da sua autonomia exercida no passado, quer pela consideração futura da sua autonomia praticada no presente. No âmbito do Direito Tributário, tal compreensão evidencia a segurança jurídica como instrumento imprescindível de realização dos princípios de liberdade, especialmente de liberdade de exercício de atividade econômica, assim como de igualdade e de dignidade humana. O princípio da segurança jurídica é, desse modo, o princípio da respeitabilidade do contribuinte como cidadão."

12. Tratando a coisa julgada como princípio e, assim, passível de ponderação em caso de conflito com outros princípios constitucionais (ROCHA, 2009, p. 166-191).

13. Tratando a coisa julgada como regra decorrente do princípio da segurança jurídica e, assim, não sendo objeto de ponderação horizontal (ÁVILA, 2016, p. 709-710).

14. O Supremo Tribunal Federal já reconheceu a constitucionalidade dos $\S \S 12$ e 14 do art. 525 do CPC/2015, sustentando o Relator, Min. Teori Zavascki, que a regra faz um adequado balanceamento da tensão existente entre os princípios da coisa julgada e da supremacia da Constituição (ADI 2.418-DF, julgada em 04/05/2016).

15. "Não cabe ação rescisória por ofensa a literal disposição de lei, quando a decisão rescindenda se tiver baseado em texto legal de interpretação controvertida nos tribunais."

16. Alguns processualistas já sugeriam regramento semelhante: "como já dissemos antes, também no caso de rescisória com o objetivo de desconstituir a coisa julgada que se forma sobre sentença proferida com base em lei posteriormente tida como inconstitucional em ação declaratória de inconstitucionalidade, o prazo só pode começar a contar a partir do julgamento da ação declaratória de inconstitucionalidade." (ALVIM, MEDINA, 2003, p. 208).

17. A Súmula 343 do STF foi criada em 13/12/1963 e decorria, em síntese, de dois argumentos jurídicos: a) sistema jurídico poderia conviver com duas ou mais linhas de interpretação, desde que não houvesse um entendimento aberrante; b) necessidade de estabilização das decisões judiciais, sob pena da ação rescisória tornar-se mais um recurso. Nos últimos anos o STF deixou de adotá-la quando houvesse violação de norma constitucional, admitindo, portanto, a ação rescisória (nesse sentido o AR 1478, Rel. Min. Ricardo Lewandowski, julgado pelo Tribunal Pleno, em 17/11/2011, DJe 31/01/2012), ante a força normativa da Constituição e a necessidade de máxima efetividade de suas normas, e porque o ajuizamento da ação rescisória seria uma oportunidade para o STF exercer seu papel de guardião da Constituição, unificando os entendimentos e preservando o princípio da isonomia. Entretanto, no julgamento do RE 590.809, Rel. Min. Marco Aurélio, em 22/10/2014, houve modificação de tal posicionamento para adoção do verbete n. 343 da Súmula, inclusive quando a controvérsia de entendimento se basear na aplicação de norma constitucional. No mesmo sentido o julgamento do AR 1415, Rel. Min. Luiz Fux, Tribunal Pleno, DJe 28/08/2015.

\section{REFERÊNCIAS}

ALEXY, Robert. On the Structure of Legal Principles. Ratio Juris. v. 13, n. 3, September 2000.

ALEXY, Robert. Teoria dos direitos fundamentais. São Paulo: Malheiros, 2008. 
ALVIM, Teresa Celina Arruda; MEDINA, José Miguel Garcia. O dogma da coisa julgada: hipóteses de relativização. São Paulo: Revista dos Tribunais, 2003.

ÁVILA, Humberto. Teoria da segurança jurídica. 3. ed. São Paulo: Malheiros Editores, 2014.

ÁVILA, Humberto. Teoria da segurança jurídica. 4 ed. rev. e amp. São Paulo: Malheiros Editores, 2016.

BANKOWSKI, Zenon. Vivendo plenamente a lei. Tradução Arthur Maria Ferreira Neto, Luiz Reimer Rodrigues Rieffel e Lucas Bortolozzo. Rio de Janeiro: Elsevier, 2007.

BARCELLOS, Ana Paula de. A eficácia jurídica dos princípios constitucionais: O princípio da dignidade da pessoa humana. Rio de Janeiro: Renovar, 2002.

BARROSO, Luís Roberto. Em Algum Lugar do Passado: Segurança Jurídica, Direito Intertemporal e o Novo Código Civil. In: Rocha, Carmen Lúcia Antunes (Org.) Constituição e segurança jurídica: direito adquirido, ato jurídico perfeito e coisa julgada. Estudos em homenagem a José Sepúlveda Pertence. 2. ed., rev. e amp. 1. Reimpressão. Belo Horizonte: Fórum, 2009.

BORGES, José Souto Maior. Segurança jurídica: sobre a distinção entre as competências fiscais para orientar e autuar o contribuinte. Revista de Direito Tributário, São Paulo, n. 100, p. 19-26, 2008.

BUSTAMANTE, Thomas da Rosa de. Princípios, regras e a fórmula de ponderação de Alexy: Um modelo funcional para a argumentação jurídica. Revista de Direito Constitucional e Internacional. São Paulo: Revista dos Tribunais, n. 54, p. 76-107, jan/mar, 2006.

BUSTAMANTE, Thomas da Rosa de. Teoria do precedente judicial: a justificação e a aplicação de regras jurisprudenciais. São Paulo: Noeses, 2012.

CAENEGEM, R. C. van. Juízes, legisladores e professores: capítulos de história jurídica europeia: palestras Goodhart 1984-1985. Tradução Luis Carlos Borges. Revisão técnica Carla Henriete Bevilacqua. Rio de Janeiro: Elsevier, 2010.

CANOTILHO, José Joaquim Gomes. Direito constitucional e teoria da Constituição. 7. ed. Coimbra: Almedina, 2003.

CAVALCANTE, Sayonara de Medeiros. A segurança jurídica em matéria tributária e sua interface com o princípio da proteção à confiança. Revista CEJ, Brasília, v. 13, n. 46, p. 113-119, jul./set. 2009.

CÔRTES, Osmar Mendes Paixão. Súmula vinculante e segurança jurídica; prefácio Luis Rodrigues Wambier. São Paulo: Revista dos Tribunais, 2008.

COSTA, Judith Hofmeister Martins. A re significação do princípio da segurança jurídica na relação entre o estado e os cidadãos: A segurança como crédito de confiança. Revista do CEJ: Centro de Estudos Judiciários Brasília, conselho de justiça federal, v. 27, p. 110-120, out/dez, 2004.

COUTO E SILVA, Almiro. Princípio da segurança jurídica no direito administrativo brasileiro. In: Celso Fernandes Campilongo, Alvaro de Azevedo Gonzaga e André Luiz Freire (Coord.). Enciclopédia jurídica da PUC-SP. Tomo: Direito Administrativo e Constitucional. Vidal Serrano Nunes Jr., Maurício Zockun, Carolina Zancaner Zockun, André Luiz Freire (Coord. de tomo). 1. ed. São Paulo: Pontifícia Universidade Católica de São Paulo, 2017. Disponível em: https://enciclopediajuridica.pucsp.br/verbete/17/edicao-1/ 
principio-da-seguranca-juridica-no-direito-administrativo-brasileiro. Acesso em: 05 nov. 2018.

DIDIER JR, Fredie, Curso de direito processual civil: introdução ao direito processual civil, parte geral e processo de conhecimento. 17. ed. Salvador: Jus Podivm, 2015.

HABERMAS, Jürgen. Direito e democracia: entre facticidade e validade, volume I. Tradução Flávio Beno Siebeneichler. Rio de Janeiro: Tempo Brasileiro, 1997.

MARINONI, Luiz Guilherme Bittencourt. Precedentes obrigatórios. 4. ed. São Paulo: Revista dos Tribunais, 2016.

MARINONI, Luiz Guilherme Bittencourt. A intangibilidade da coisa julgada diante da decisão de inconstitucionalidade: impugnação, rescisória e modulação de efeitos. Revista de processo, São Paulo, v. 41, n. 251, (jan. 2016) p. 275-307.

NIEVA FENOLL, Jordi. Coisa julgada. Tradução Antonio do Passo Cabral. São Paulo: Revista dos Tribunais, 2016. (Coleção Liebman).

PAULSEN, Leandro. Segurança jurídica, certeza do direito e tributação: a concretização da certeza quanto à instituição de tributos através das garantias da legalidade, da irretroatividade e da anterioridade. Porto Alegre: Liv. do Advogado, 2006.

PORTO, Éderson Garin. O dever de colaboração como vedação a operações-surpresa e comportamentos contraditórios da administração tributária. Interesse Público, Belo Horizonte, v. 18, n. 98, p. 147-179, jul./ ago. 2016.

REICHELT, Luis Alberto. Reflexões sobre a relativização da coisa julgada no novo código de processo civil. Revista de Processo. São Paulo, v. 41, n. 255, p. 167-180, maio 2016.

ROCHA, Carmen Lúcia Antunes. O princípio da coisa julgada e o vício de inconstitucionalidade. In: ROCHA, Carmen Lúcia Antunes (Org.) Constituição e segurança jurídica: direito adquirido, ato jurídico perfeito e coisa julgada. Estudos em homenagem a José Sepúlveda Pertence. 2. ed., rev. e amp. 1. Reimpressão. Belo Horizonte: Fórum, 2009.

RODRIGUES, Marilene Talarico Martins. Segurança jurídica em matéria tributária. Revista Fórum de Direito Tributário: RFDT, Belo Horizonte, v. 14, n. 83, p. 59-78, set./out. 2016.

SARLET, Ingo Wolfgang. A Eficácia do Direito Fundamental à Segurança Jurídica: Dignidade da Pessoa Humana, Direitos Fundamentais e Proibição de Retrocesso no Direito Constitucional Brasileiro. In: Rocha, Carmen Lúcia Antunes (Org.) Constituição e segurança jurídica: direito adquirido, ato jurídico perfeito e coisa julgada. Estudos em homenagem a José Sepúlveda Pertence. 2. ed., rev. e amp. 1. Reimpressão. Belo Horizonte: Fórum, 2009.

SILVA, José Afonso da. Constituição e Segurança Jurídica. In: ROCHA, Carmen Lúcia Antunes (Org.) Constituição e segurança jurídica: direito adquirido, ato jurídico perfeito e coisa julgada. Estudos em homenagem a José Sepúlveda Pertence. 2. ed., rev. e amp. 1. Reimpressão. Belo Horizonte: Fórum, 2009.

TABORDA, Maren Guimarães. Transparência, direito fundamental de acesso e participação na gestão da coisa pública: exposição de motivos ao Projeto de Lei de processo administrativo no município de Porto Alegre. In: GAVIÃO FILHO, Anizio Pires; LEAL, Rogério Gesta (Org.). Bens Jurídicos Indisponíveis e 
Direitos Transindividuais. E-book. Porto Alegre: FMP, 2015.

TEODOROVICZ, Jeferson. Segurança jurídica no direito tributário e modulação dos efeitos em decisões de inconstitucionalidade. Revista Tributária e de Finanças Públicas, São Paulo, v. 24, n. 131, p. 65-125, nov./dez. 2016.

Recebido em: 13/03/2019

Aceito em: 05/06/2019 